Article

\title{
The Role of SMEs' Green Business Models in the Transition to a Low-Carbon Economy: Differences in Their Design and Degree of Adoption Stemming from Business Size
}

\author{
María A. Quintás, Ana I. Martínez-Senra * (iD and Antonio Sartal \\ Department of Business Management and Marketing, Faculty of Economics, Universidad de Vigo, \\ Campus Universitario, s/n, 36310 Vigo, Spain; quintas@uvigo.es (M.A.Q.); antoniosartal@uvigo.es (A.S.) \\ * Correspondence: aimtnez@uvigo.es; Tel.: +34-986813543
}

Received: 22 May 2018; Accepted: 16 June 2018; Published: 20 June 2018

\begin{abstract}
The purpose of this paper is to analyze how SMEs define the components of their business models (value proposition, creation and capture) from the point of view of decarbonization. We analyze SMEs as a group, and study whether their size affects this process and, in both cases, we examine evolution over time. We use a database comprising 1161 observations of SMEs, 466 in 2014, and 695 in 2016. The results show that SMEs' value propositions give an intermediate valuation to both legally required and voluntary reduction of environmental impact, irrespective of SME size and the year analyzed. Regarding value creation, SMEs adopt practically no environmental practices, and there are significant differences according to size, with more difficulties than advantages stemming from small size. The study also shows that such environmental practices are not effective in reducing carbon. This diagnosis indicates that SMEs need help from the administration if they are to play a key role in the process of transformation toward a low-carbon economy. Legislative actions involving harsher environmental protection measures might help shape value propositions that place greater importance on reducing environmental impact, whereas training actions on available environmental techniques, promotion of research on how to adapt such techniques to SMEs and the development of specific practices for SMEs might enhance environmental value creation and capture in their BMs.
\end{abstract}

Keywords: green business models; decarbonization; SMEs; size

\section{Introduction}

This study falls within the framework of the Great Climate Challenge [1,2]. It analyzes how small and medium enterprises (SMEs) include decarbonization in their business models (BMs) and how their size affects the design and implementation of such models.

Although there have been many initiatives aiming to cut greenhouse gas emissions and hold back the negative consequences of global warming since the Rio Summit (1992) and the Kyoto Protocol (1997), $\mathrm{CO}_{2}$ emissions have continued to increase year after year [3]. The most optimistic estimates indicate that more than half the level of greenhouse gases that would generate global warming in excess of $2{ }^{\circ} \mathrm{C}$ above the preindustrial level [4] have already been emitted and are accumulating in the atmosphere. In an attempt to stop this process, a large proportion of the international community signed the Paris Agreement in 2015 to reduce emissions during the period from 2050 to 2100 . This is an ambitious commitment in which energy efficiency and early reductions of $\mathrm{CO}_{2}$ emissions are key [5], especially in businesses [6,7]. 
In view of the role of businesses in the sustainable development of society [8,9], it seems surprising that the environmental strategy literature started to cover decarbonization so late [10,11]. Undoubtedly, through some areas such as institutional theory [12,13], stakeholder theory [14-16] or resource-based theory [17-19], knowledge has increased regarding some of the institutional and organizational factors that explain the level of adoption of environmental strategies. However, given the evidence on the constant rise in levels of anthropogenic $\mathrm{CO}_{2}[6,20]$, these approaches seem to have been insufficient for promoting the transition toward a low-carbon economy [21]. In this situation, BMs, understood as the set of activities and processes carried out by firms when defining the value proposition, creation and capture for their stakeholders [22-24], might be an appropriate tool to achieve this transition [25].

The few studies that have specifically analyzed the topic of BMs and decarbonization focus on the energy sector [25-28]. Others, falling under the literature related to Green BMs [29,30] and Sustainable BMs [23,31,32], cover different environmental aspects associated with BMs, but without focusing explicitly on decarbonization. In addition, although SMEs account for about $99 \%$ of the business fabric of EU countries [33] and are jointly responsible for a large volume of the environmental impact [34], which many authors set at about 70\% (this figure has attained a mythical status, albeit unjustifiably, because national economic statistics on SMEs do not usually include data on emissions, so it is debatable whether SMEs' contribution to contamination can be calculated [34], however, we agree with Hillary that given the large number of SMEs in the main economies, collectively, they have a great environmental impact [34]) [35-37], most studies focus on large corporations, while the study of SMEs is limited to the analysis of certain cases with a proactive attitude [31,38].

In this context, we focus on SMEs to analyze their BMs from the point of view of decarbonization. Specifically, we analyze to what extent SMEs as a group consider environmental aspects when defining their value proposition, creation and capture. Moreover, since SMEs are a very heterogeneous group by size, we analyze whether size differences affect this process. Finally, we also study the evolution of the process over time.

From a theoretical point of view, our contribution covers three aspects. First, in the literature on green BMs and sustainable BMs, we include the literature on decarbonization, an important topic which, nevertheless, is not explicit in most of this literature [23,32,39], with a few exceptions in the energy sector $[25,40]$. Second, we focus on SMEs that, in general, have been understudied, except for some case studies showing selection bias toward environmental proactivity [28,41,42]. Third, we search for differences in the degree of incorporation of decarbonization in SMEs' green BMs depending on their size because both the traditional literature on environmental strategy and that on BMs point to different barriers and enablers for the development of environmental strategies and BMs depending on size $[43,44]$.

From a strictly empirical point of view, our paper has certain strengths: (1) It is a quantitative exploratory analysis [45], although the literature mostly comprises case studies [7,28]; (2) we work with a database with information on 466 SMEs in 2014 and 695 in 2016, without establishing any bias toward the environmental proactivity that can be found in many previous studies [42,43]; (3) we present a multisector study, in contrast to studies that focus on a single sector [25,46,47]; and (4) we work in a three-year time frame because innovation processes in BMs are long and have many complex effects on business performance [48].

The paper is structured as follows. In Section 2, we analyze how businesses have included environmental matters in their strategies. We then study the elements that make up green BMs, how decarbonization is included in their products and processes, and the influence of size on this configuration. Section 3 describes the sample of businesses and the methodology used. We then explain the results of our analysis, draw the main conclusions, and describe their implications for business management and public policy. 


\section{Conceptualization of BMs: Their Role in Environmental Decarbonization}

\subsection{Delimitation and Definition of BMs}

BMs have been generating increasing interest among managers and researchers since the 1990s with the growth of dotcom companies [49]. Intuitively, a BM could be defined as a description of an organization and of how it functions to meet its goals-profitability, growth, social impact, etc. [50]. However, going beyond that intuitive idea, there is still no consensus on how to define the BM concept $[45,50-53]$. The multidimensional nature of BMs makes it difficult to build a theory around them $[52,54]$. Their definition and conceptualization have varied depending on the purpose of the research and the theoretical approach adopted by researchers [53]. It is, therefore, important for researchers to give a precise definition of the BM concept used in their research [52].

In this study, of the three possible interpretations that researchers have given to BMs-attributes of a real firm, cognitive or linguistic outline, or conceptual representation [50] -we use the most specific concept possible, that is, the attributes of a real firm. We consider BMs to be the set of activities and processes carried out by a firm [31] that allow it to define how to propose, create and capture value for its stakeholders [22-24]. More specifically, we consider that an organization's BM reflects the strategy adopted and comprises the set of choices made by the firm based on its strategy and the consequences of the latter [24]. We therefore place the BM between the strategy level and the operational level. This idea is shared by a large number of authors, both theoretically $[22,24,55]$ and empirically $[42,56]$.

BMs themselves may also be subject to innovation $[48,57]$. When creating or adapting a BM, alternatives to current ways of doing business have to be explored, and it is important to understand how firms can meet their customers' needs in different ways. Executives have to learn to question existing models and to act entrepreneurially in order to develop new delivery mechanisms [58]. The search for sustainability is starting to transform the way in which firms compete, so they may be forced to change the way they see products, technologies, processes, and BMs [58].

\subsection{Integrating Environmental Aspects Associated with Climate Change in BMs}

Integrating climate change in business strategies is one of the main challenges faced by firms today [2]. They are under increasing pressure from governments and stakeholders to reduce their $\mathrm{CO}_{2}$ emissions and, thus, mitigate climate change [11]. However, even though there is no alternative to sustainable development [58], firms have not included the management of their $\mathrm{CO}_{2}$ emissions in their strategies [1].

Traditionally, institutional theory [12,13], stakeholder theory [14-16] and resource-based theory $[17-19,59]$ have helped improve knowledge of the determinants of environmental strategies and of the institutional and organizational factors that broadly explain such strategies. However, such studies have not dealt specifically with the incorporation of climate change in environmental strategies. It was only in the second half of the first decade of the 21st century that a large number of studies started to appear focusing on climate change strategy and carbon reduction [60-63]. Since then, interest has grown, and in recent years, many works have analyzed a range of subjects, among them carbon reduction strategies and practices $[2,11,64,65]$; barriers to and enablers of such strategies $[66,67]$; and the effects that carbon reduction strategies and practices have on economic and environmental performance $[6,68]$. Although much of this literature analyzes business size, the results are not clear. For example, regarding the relation between carbon reduction strategies and business size, some authors find no significant differences between firms of different size [65], while others state that in large enterprises, the degree of adoption is greater, but there is no clear correspondence with $\mathrm{CO}_{2}$ emissions [2,11].

Although this literature has improved knowledge regarding the determinants of environmental strategy, strategic vision seems insufficient to achieve the transformation that organizations need for the transition to a low-carbon economy $[21,38]$. More overarching approaches are necessary to assess 
carbon reduction strategies and their consequences, and BMs may be an appropriate tool for this. The formulation of green BMs forces managers to reflect on how firms can propose, create, and capture environmental value in their processes, products and services [23,30,32].

According to Mangelsdorf [21], the process of decarbonization at a normal rate would take 50 years, which is too long if we are to reach the environmental goal of limiting global warming to $2{ }^{\circ} \mathrm{C}$. However, BMs can speed up this process $[21,25,69]$. Some recent studies have analyzed the three possible roles that BMs can play in processes to transform societies into low-carbon economies $[25,40]$. The first of them makes it difficult for new green BMs to enter, while the last two might make it easier to disseminate and adopt them.

Regarding the first, BMs form part of today's socio-technical regime and are based on the standard modus operandi in the sector. This role helps them to maintain links with other related sectors, so in this case, BMs act by strengthening current regimes and BMs and establishing barriers for new BMs, in our case, green BMs. an example of this role can be found in the BMs of large electricity utilities. They used control over complementary assets such as the grid infrastructure to keep renewable technologies out of the system, and took actions against friendly renewable regulation. Furthermore, they joined forces with other regime actors, such as suppliers of conventional power plant components and grid device manufacturers whose business models also depended on the survival of the traditional regime. This shows the mutually reinforcing effect of the traditional regime and existing business models [40].

Regarding the second, existing or new BMs can serve for marketing technological innovations, making it possible to demonstrate the value of new technologies, facilitating the expression of expectations among different agents and allowing more technological links to be created among more agents, thus creating networks of value around the technological innovation. In fact, a suitable BM might be more relevant than the technology itself for its success. The VHS and Betamax video technologies are an example of how the market can adopt a worse-quality technology but with a more appropriate BM.

Finally, BMs themselves may be subject to innovation, irrespective of the technologies involved, and may change the modus operandi in a sector. This happens when new methods of creating and capturing value have reached a critical mass of agents in a new value network. Examples abound of new business models that have quickly been transformed or have even become obsolete in a range of sectors including media (decline of print), retail (online retailing and sharing platform), music (digital music devices and services), telecommunications (proliferation of smartphones and associated services) and even finance (peer to peer lending) [70].

The last two of these roles are especially useful for SMEs that want to transition toward a low-carbon economy because they help them overcome the barriers imposed by the BMs of established firms. The literature describes cases such as that of NativeEnergy, an SME in the renewable energy sector with 15 workers at the time of the study, which, thanks to an innovation in its BM, was able to become the leader in its sector, with activity throughout the US and in Alaskan native villages [41]. Furthermore, innovation in BMs may be a good option for SMEs to include responsible innovation in their firms rather than other more costly and complex types of innovation [71]. However, in spite of the potential for making climate change and carbon management a main pillar of their BMs, the current degree of integration in firms is not known [1], and this is especially true for SMEs. There have been few studies on BMs and decarbonization in SMEs, and the ones that exist focus on the energy sector $[28,41]$.

On the other hand, more general literature on Green BMs and Sustainable BMs (the main difference between green and sustainable BMs is that the former focus on environmental aspects and the latter include social aspects. In this study, we do not analyze the three pillars of sustainable development-economic, social, and environmental-[72] because decarbonization is included in the environmental pillar, thus, from now on, we shall use the term green BMs) covers more sectors, but does not deal explicitly with decarbonization. In many cases, studies are theoretical, and most of 
the empirical studies focus on large corporations [31,73]. Therefore, the study of SMEs is limited to the analysis of certain cases, but again, there is a selection bias toward environmental proactivity [42,74].

Our study aims to fill this gap that has been detected in the literature by analyzing how SMEs include environmental aspects in their green BMs and to what extent these facilitate decarbonization. We define green BMs by extrapolating the structure of BMs to the environment in three components: value proposition, creation and capture for the firm and for its stakeholders [22,24]. This extrapolation has already been performed by other authors, such as Bocken et al. [23], in the environmental and social area. By means of an exploratory study, we quantify the degree of integration being achieved from a multisector point of view and take into account the effects of SME size. We include this variable in our analysis because size may have an ambivalent role, either promoting or hindering environmental efforts [75,76], and because, among SMEs, there is great diversity [43] that makes it necessary to break down the study by size $[77,78]$.

\subsubsection{Green BMs: Environmental Value Proposition}

The value proposition of a BM is related to the firm's strategic positioning. It defines what it will deliver to its customers, what characteristics customers will be prepared to pay for, and the firm's basic approach to obtaining competitive advantages [22]. From an environmental point of view, the value proposition in a BM should provide measurable ecological and social value in relation to the economic value [32,38]. When defining it, firms should consider the environmental needs of the firm's stakeholders because these should determine the strategic drivers for corporate sustainability, emphasizing the main corporate goals for adopting win-win environmental solutions [79].

However, the analysis of stakeholder needs is subject to the perception of firms' managers. This means we may find firms that are subject to the same institutional pressure but that react to it differently $[12,80]$. Factors, such as the company culture or idiosyncrasy, the internal organization of departments, and the sources of information they use [12], as well as the degree of environmental maturity [81] or personal values and beliefs [42,43], may lead firms to perceive, interpret, and respond differently to stakeholders' needs / pressure. Additionally, it should be remembered that not all firms are subject to the same pressures. Market leaders, multinationals, or firms that were historically less environmentally friendly may be subject to greater pressure [12].

Differences in stakeholder pressure and different interpretations of such pressure will lead to different environmental strategies and, therefore, to different value propositions in BMs. There will be firms that only comply with sector regulations and others that want to keep their stakeholders happy and, thus, consider environmental strategies that allow them to reduce the environmental impact of their operations beyond regulatory requirements [19].

It is, therefore, in the value proposition of green BMs that managers will express their commitment to the environment. There will be green BMs in which the value proposition focuses on complying with compulsory regulations, but there will be others that go further than this, aiming to voluntarily reduce the environmental impact of their products and activities. We believe that it will be in the latter that green BMs will be developed in which value creation and capture will be more committed to decarbonization.

With respect to size, we believe it may affect the definition of the value proposition of micro, small and medium firms because micro and small firms are less visible than medium firms and are, therefore, subject to less external pressure [77]; additionally, smaller (and micro) SMEs may think it is not necessary to comply with regulations [82]. Many SMEs see requirements to include environmental aspects in their strategy as a cost that cannot be transferred to their customers in terms of added profit, and few of them consider that managing such aspects will allow them to achieve a competitive advantage [83].

In addition, owner/managers of micro and small firms often enjoy greater decision-making freedom than the managers of medium firms. Their personal responsibility and their motivations therefore have a greater influence on the management of the business $[84,85]$ and may lead them to be 
more committed to climate change [43]. Since size, therefore, has a controversial role, we will analyze its influence on the definition of value propositions in green BMs.

\subsubsection{Green BMs: Creation and Delivery of Environmental Value}

The creation and delivery of value make it necessary to establish how the firm will compete to put into practice its value proposition [22,79]. This is the heart of any business model [23] and includes the resources, activities, and key processes, as well as links with suppliers, partners, and clients, that will allow the value proposition to be implemented [22,23]. When the creation and delivery of value are designed, the value proposition and capture must be borne in mind [22].

In our case, green BMs must define their creation and delivery of environmental value bearing in mind the proposition and capture of environmental value. The value proposition must improve the firm's environmental impact (voluntarily or because it is required by law). The capture of value, to be explained in the next section, aims to reduce $\mathrm{CO}_{2}$ emissions in order to achieve product and process decarbonization in green BMs. Therefore, in view of this value proposition and capture, the creation and delivery of environmental value must be carried out using the resources, activities, and processes that make it possible to reduce environmental impact by decarbonizing products and processes.

We identify nine voluntary practices, which go beyond end-of-pipe practices and really allow the creation and delivery of environmental value. This is not a full list of all proactive environmental management practices, but all of them are relevant for the environmental management of products and processes and/or firms' energy management. End-of-pipe technologies are not included because we consider that they do not generate value but, rather, may amount to an unproductive cost for firms [86]. We also consider that firms in which prevention technologies carry greater weight than in those that only have end-of-pipe technologies will be more successful in reducing their environmental impact [86]. Below is a description of how these nine practices can help generate environmental value in the transition toward a low-carbon economy.

(i) Energy and environmental audits. Audits are useful tools for helping firms to better understand their environmental behavior. a full audit can help identify potential energy savings of $15-30 \%$ in an SME, whatever its economic activity or number of employees [87]. The slogan "If you can't measure it, you can't manage it" can be applied to resources and costs as well as to carbon emissions. It, therefore, seems important to identify and manage emissions of carbon and other contaminants for both companies in regulated sectors that are legally required to quantify their emissions and those in non-regulated sectors that voluntarily calculate and publish their carbon emissions [88].

(ii) Product life cycle and (iii) ecological design. These two techniques that are used in sustainable manufacturing allow any product or process to be analyzed in terms of improved environmental performance, quality and competitiveness, while also minimizing manufacturing costs [89]. Eco-design is very important because $80 \%$ of product sustainability impacts are decided on during the product design and development stage [89]. Life cycle analysis is a key tool to help guarantee sustainability by assessing the environmental impact of product designs [90] and is used to analyze the carbon footprint of SMEs [91].

(iv) Eco-labeling. Eco-labeling (also known as environmental labeling or carbon labeling) is another environmental practice, of a voluntary nature, that has received significant interest worldwide [92,93]. an eco-label identifies a proven environmental distinction of a product or service within a specific product or service category. Eco-labels are, therefore, an explicit way of showing the environmental quality of products [94]. From the point of view of a company, voluntary eco-labeling programs can set it apart from its competitors and offer flexibility to take on commitments to improve its environmental performance beyond what is required by law [94]. 
Eco-labeling is being applied in a variety of sectors such as construction, agriculture, fashion, tourism, and consumer products [93,95-97]. However, not all eco-labels are necessarily directly related to $\mathrm{CO}_{2}$ emission reduction. For example, in the tourism sector, of the 128 eco-labels studied by Gössling and Buckley [96], 51 do not consider energy saving or greenhouse gas emissions, and in the fishing sector, decarbonization of fish products is rarely covered by eco-labels [95].

(v) Best available techniques (BATs) for attaining lower consumption of resources and/or environmental impact. Depending on the characteristics of the different carbon-intensive industrial processes, new technologies can reduce $\mathrm{CO}_{2}$ emissions. Due to the wide range of industries and industrial processes, there is also a wide range of possible technological improvements [65]. In this context, the identification, evaluation and selection of the best available techniques (BATs) to improve critical environmental points in production processes can achieve very relevant environmental improvements [98]. Moreover, analysis of BATs can also be applied together with other environmental practices, thus enhancing their energy efficiency. For example, in cogeneration and trigeneration, the technologies available for combined production can help increase the degree of emission reduction [99].

(vi) Recycling, reuse and/or valorization of sub-products and waste products. Recycling is defined as a method for recovering resources that involves the collection and processing of waste products to be used as raw materials in the production of the same or a similar product. The EU's waste strategy makes a distinction between reuse and recycling. Reuse means using waste as a raw material in a different process with no structural change, and recycling refers to structural changes in the materials within the same process [100]. These complex processes are used in many industries, such as construction [101] and electronics [102], and allow the firms using them to be more environmentally friendly. Burke and Gaughran [103] indicate that $83 \%$ of Irish SMEs are involved in waste minimization and recycling.

(vii) Waste and recycled materials for generating energy. Unprecedented, cheap technological progress over recent centuries has increased waste generation. Furthermore, waste has increased not only in quantity, but also in heterogeneity and complexity and in the creation of new, sometimes hazardous, substances (plastics, dyes, paints, drugs, electronic components, etc.) [104].

Waste incineration helps protect the environment by preventing dangerous organic waste from reaching it. Additionally, low-carbon energy can be generated from waste, thus reducing greenhouse gas emissions [104]. Attempts are being made today to recover materials from waste produced in the actual process of power generation [104], thus reducing $\mathrm{CO}_{2}$ emissions. Furthermore, the use of cotton waste might be a viable, cheap, and environmentally friendly alternative for producing thermal energy [105].

(viii) Cogeneration and trigeneration. Cogeneration systems, which are combined systems for producing both heat and power, are known to save a considerable amount of power in comparison with the separate production of the same amount of heat (from conventional combustion generators) and power (from conventional power stations) [106]. Trigeneration systems are based on combined heat and power systems coupled with absorption coolers that use cogeneration. Therefore, the heat that would be wasted during the summer because of a lack of demand can be effectively exploited to produce power for cooling, for use in air conditioning systems. As a consequence of their improved energy performance, cogeneration and trigeneration systems can also bring important environmental benefits in terms of greenhouse gas reduction $[99,107,108]$.

(ix) Adoption of renewable energies (wind, photovoltaic, geothermal, solar-thermal energy). Renewable energy sources, also called alternative energy sources, are resources that can be repeatedly used to produce energy, such as solar, wind, or geothermal energy. Renewable energy technologies are considered clean and, when used optimally, they minimize environmental impact, produce minimal secondary waste, and are sustainable from the point of view of current and future social and 
economic needs [109]. Therefore, replacing fossil fuels with renewable sources of energy reduces the environmental impact and the $\mathrm{CO}_{2}$ emitted into the atmosphere.

The inclusion of these practices in green BMs should generate and deliver environmental value so that the environmental proposition can be put into practice (complying with environmental requirements and reducing environmental impact) while capturing the value (reduction of $\mathrm{CO}_{2}$ emissions) that green BMs seek. We consider that the more such practices are included in green BMs, the more environmental value they will generate and capture.

In addition, when these techniques are applied, firms should be innovative and critical of the systems they are using so that they can identify any uncaptured value. The identification of any uncaptured (superfluous, absent, lost, or destroyed) value may trigger the discovery of new opportunities for creating, delivering, and capturing value and may lead to innovation in sustainable BMs [49]. This approach will therefore facilitate innovation in Green BMs and increase the possibility of stepping up decarbonization of SMEs' products and processes.

Business size also affects the creation and delivery of environmental value because it may hinder or facilitate the number of practices that businesses include in their green BMs. It is more difficult for micro and small firms to consider and adopt several strategic options in response to climate change than for medium firms [77], mostly due to lack of knowledge and of human and financial resources [110] and because of their dependence in most cases on a small number of clients. However, small enterprises are more flexible and less tied to formalities so they can adapt to change faster [75,111]. Furthermore, their owner-managers are freer to change the business's strategic direction [112], which may lead them to a greater commitment to climate change [43] and may encourage them to adopt a larger number of environmental practices.

We shall therefore explore, on the one hand, the most common practices for creating and delivering environmental value in green BMs and their most frequent combinations and, on the other hand, if there are differences stemming from business size in both the types of environmental practices and their combinations.

\subsubsection{Green BMs: Capturing Environmental Value by Increasing Carbon Productivity}

Value proposition, creation and delivery do not guarantee business success if the firm does not capture value [22], or, as some people put it, does not appropriate value [113,114]. The relation between the dimensions of value creation and capture/appropriation is therefore key in BMs [115].

The traditional literature on BMs points to elements of cost and revenue structure for measuring value capture $[55,116]$, while the literature on green and sustainable BMs includes other forms of non-monetary value capture $[23,74]$. This difference is because, in the context of corporate sustainability, economic results are insufficient for ensuring sustainable value capture [79] because environmental and social value must also be included [49].

In our study, which analyzes if the green BMs of SMEs are helping to achieve decarbonization of the economy, we will measure value capture by quantifying their $\mathrm{CO}_{2}$ emissions. This measure covers environmental value because it quantifies, with the aim of reducing, the main greenhouse gas. In addition, this way of seeing value capture can be said to be present in the three archetypes of sustainable technological BMs identified by Bocken et al. [23], who talk about "minimized environmental footprint," "reduced footprint", and "reducing emissions associated with burning fossil fuels." The green BMs of SMEs should try to generate value with low $\mathrm{CO}_{2}$ emissions and, if possible, to reduce such emissions over time.

Because the possible financial benefits of saving and the efficiency of resources resulting from applying environmental improvements are usually smaller in micro and small firms than in medium firms $[75,77]$, again, we analyze how size affects the stage of environmental value capture. 


\section{Data and Methodology}

We used a database with economic and environmental microdata from 466 SMEs in 2014 and 695 in 2016 (1161 observations). The data was obtained from the GIS survey [117]. This is the largest survey of business innovation in the northwest of Spain. Coordinated by the Galician Innovation Agency (GAIN), this annual online questionnaire provides a unique opportunity because it allows us to analyze in depth the two areas of interest in our research: sustainable BM pillars and decarbonization. The surveys for 2014, 2015, and 2016 are currently available. We used those for 2014 and 2016 to analyze the changes that took place during that period.

Regarding the submission process, the contact person was always a top-level informant (manufacturing manager, industrial/operations director or CEO, depending on the size of each company) with a global perspective and knowledge (or access to information) about the industrial and business requirements. According to Phillips [118], top-level informants tend to be more reliable sources of information than lower-level employees. Furthermore, random phone calls to non-response companies were made, and no specific pattern was evident in these cases or in the reasons given for non-response. There is no evidence, therefore, that responses were only received from a specific type of company, and it is not necessary to consider the non-response bias that may occur in online surveys. Similarly, a comparison of early and late responses [119] found no statistically significant differences in any of the study variables. Table 1 shows the distribution of firms by size (employees), turnover, and sector.

Table 1. Distribution of SMEs by size, turnover, and sector.

\begin{tabular}{|c|c|c|}
\hline Characteristics & $2014(\%)$ & $2016(\%)$ \\
\hline \multicolumn{3}{|l|}{ Size } \\
\hline Micro: $\leq 10$ workers & 8 & 7 \\
\hline Small: $11-50$ workers & 77 & 73 \\
\hline Medium: 51-250 workers & 15 & 20 \\
\hline \multicolumn{3}{|l|}{ Turnover } \\
\hline 2-10 €M. & 41 & 39 \\
\hline $11-50 € \mathrm{M}$ & 10 & 12 \\
\hline $51-100 € \mathrm{M}$ & 2 & 1 \\
\hline Over $100 € \mathrm{M}$. & 27 & 28 \\
\hline \multicolumn{3}{|l|}{ Sector } \\
\hline $\begin{array}{l}\text { High and medium-high } \\
\text { technology }\end{array}$ & 18 & 15 \\
\hline Low and medium-low technology & 82 & 85 \\
\hline
\end{tabular}

Regarding the environmental value proposition, we distinguish between legally required or voluntary reduction of environmental impact. For the former, we built a categorical variable that assesses the importance placed by the SME on the degree of compliance with environmental requirements as a goal of its innovation activity. Similarly, for the latter, we asked about the importance of obtaining a lower environmental impact. In both cases, the valuation was rated on a three-point Likert scale, with 1 meaning little importance, 2 meaning medium importance, and 3 meaning high importance.

To measure value creation, we asked about the use of nine voluntary practices that go beyond end-of-pipe practices and really allow for the creation and delivery of environmental value, helping to generate environmental value for a transition toward a low-carbon economy: (i) energy and environmental audits, (ii) life cycle analysis, (iii) ecological design, (iv) eco-labeling, (v) best available techniques, (vi) valorization of sub-products and waste, (vii) use of waste to generate power, (viii) cogeneration and trigeneration and, finally, (ix) use of renewable energies [120]. We then built a continuous variable with values from 0 to 9 indicating the number of practices used by each firm. 
Finally, to explore if green BMs are helping to achieve decarbonization of the economy, the value capture of a green BM was measured by the inverse of one of the most common indicators in the fight against climate change and the upcoming circular economy monitoring framework: carbon intensity: the ratio of $\mathrm{CO}_{2}$ emissions to revenue [121-124]. This measure (Equation (1)) is used by researchers and institutions as a policy instrument (e.g., national targets and emission pledges) for valuing emission reduction potential and progress on decarbonization at the sector level $[125,126]$. The Green Growth initiative in the OECD, for example, includes this ratio as an environmental decoupling indicator [127]:

$$
\text { Carbon Prod }=\text { Total Revenue } / \sum_{x 1}^{x 5} \mathrm{CO}_{2} \mathrm{eq}
$$

where the subscript $x$ identifies the different energy sources in each $\mathrm{SME}$, measured as $\mathrm{CO}_{2}$ equivalent $\left(\mathrm{CO}_{2}\right.$ eq) in $€$ : electricity, natural gas, fuel oil, gas oil, and GLP (butane and propane).

To measure the size of the SMEs, we used the number of employees, distinguishing between micro (up to 10 employees), small (from 11 to 50 employees), and medium (from 51 to 250 employees) enterprises. Table 2 shows the main descriptive statistics for these variables for 2014 and 2016.

Table 2. The main descriptive statistics.

\begin{tabular}{lcccccccccc}
\hline & \multicolumn{3}{c}{$\mathbf{2 0 1 4}$} & \multicolumn{3}{c}{$\mathbf{2 0 1 6}$} \\
\cline { 2 - 12 } & $\mathbf{N}$ & Mean & STD & Min. & Max. & N & Mean & STD & Min. & Max. \\
\hline Legal proposition & 323 & 2.06 & 0.78 & 1 & 3 & 485 & 2.04 & 0.74 & 1 & 3 \\
Voluntary proposition & 320 & 1.95 & 0.76 & 1 & 3 & 475 & 1.95 & 0.73 & 1 & 3 \\
Value creation & 466 & 1.1 & 1.52 & 0 & 9 & 695 & 1.25 & 1.53 & 0 & 7 \\
Value capture & 365 & 52.9 & 129.1 & 0.04 & 1592.1 & 557 & 62.87 & 133.9 & 0.10 & 1443.8 \\
Size & 466 & 2.07 & 0.46 & 1 & 3 & 695 & 2.13 & 0.51 & 1 & 3 \\
\hline
\end{tabular}

With these variables and by carrying out an exploratory analysis, we studied how SMEs define their BMs from the point of view of decarbonization. For each BM component (value proposition, creation and capture), we first performed a descriptive analysis for the SMEs as a group then analyzed if there are differences in means between SMEs of different size using the Kruskal-Wallis test and, finally, using this same test, we studied time differences in both analyses.

We employ the Kruskal-Wallis test because it is a non-parametric method (it does not assume normal distribution of the residuals) for testing whether samples originate from the same distribution. It is used for comparing two or more groups of equal or different sample size. Both the Kruskal-Wallis test and one-way ANOVA assess significant differences on a continuous dependent variable using a categorical independent variable but, since the Kruskal-Wallis test is a non-parametric method, it can be used when (as here) the assumptions of ANOVA are not met, namely, with normal distribution and approximately equal variance across groups.

\section{Results}

With the information from this database, we performed an exploratory analysis to test how the SMEs include product and process decarbonization in their components (value proposition, creation, and capture); to what extent this inclusion depends on the size of the SME, because the literature points to several barriers and enablers for developing environmental strategies and BMs that depend on size [43,44]; and, finally, how defining BMs becomes a long process with many complex effects for the firm's performance. We also studied the evolution over time of the inclusion of decarbonization in the value proposition, creation and capture, and the effect of size. In both cases, we used the non-parametric Kruskal-Wallis test. 


\subsection{Green BMs: Value Proposition}

SMEs place medium importance in their value proposition on compliance with both the legally required and voluntary reduction of the environmental impact of products and services, with medium values in 2016 of 2.04 and 1.95, respectively. Regarding how this inclusion takes place in terms of business size (Table 3), we observed no significant differences between the three types of enterprise (micro, small and medium) in the definition of the environmental value proposition, the importance placed on innovation for legal compliance or the reduction of the voluntary environmental impact.

Table 3. Value proposition: differences by size.

\begin{tabular}{cccc}
\hline \multirow{2}{*}{ Size } & \multicolumn{2}{c}{ Value Proposition } \\
\cline { 3 - 4 } & & Legal & Voluntary \\
\hline \multirow{2}{*}{ Average values } & Micro & 2.38 & 2.12 \\
& Small & 2.02 & 1.93 \\
& Medium & 2.03 & 1.99 \\
\hline \multirow{2}{*}{ Kruskal-Wallis test } & Chi-squared & 5.295 & 2.0666 \\
& Asymptotic sig. & 0.071 & 0.356 \\
\hline
\end{tabular}

In addition, the analysis of evolution over time shows that there were no important changes in the definition of the value proposition by the SMEs after 2014. Table 4 shows that there are no significant differences either globally or in terms of SME size.

Table 4. Value proposition: evolution over time, globally, and by size.

\begin{tabular}{|c|c|c|c|c|c|c|c|c|c|}
\hline & & \multicolumn{2}{|c|}{ All SMEs } & \multicolumn{2}{|c|}{ Micro } & \multicolumn{2}{|c|}{ Small } & \multicolumn{2}{|c|}{ Medium } \\
\hline & & Legal & Voluntary & Legal & Voluntary & Legal & Voluntary & Legal & Voluntary \\
\hline Average & 2014 & 2.06 & 1.95 & 1.95 & 1.83 & 2.07 & 1.95 & 2.02 & 2.02 \\
\hline values & 2016 & 2.04 & 1.95 & 2.38 & 2.12 & 2.02 & 1.93 & 2.03 & 1.99 \\
\hline \multicolumn{10}{|c|}{ Kruskal-Wallis } \\
\hline Chi-squ & dared & 0.189 & 0.002 & 3.648 & 1.946 & 0.931 & 0.155 & 0.004 & 0.064 \\
\hline Asympto & tic sig. & 0.664 & 0.966 & 0.056 & 0.163 & 0.335 & 0.694 & 0.948 & 0.801 \\
\hline
\end{tabular}

\subsection{Green BMs: Value Creation}

Regarding value creation, the SMEs in the sample continue to include a very low number of environmental practices, on average about one (1.25 in 2016) out of the nine covered in the survey (Table 2). a significant difference was noted in the average value of the number of environmental initiatives among enterprises of different sizes, with medium enterprises using a larger number of practices (1.61), followed by small enterprises (1.21) and micro enterprises, which, on average, do not reach one (0.75) (Table 5).

Table 5. Value creation: differences by size.

\begin{tabular}{ccc}
\hline & Size & Value Creation \\
\hline \multirow{3}{*}{ Average values } & Micro & 0.75 \\
& Small & 1.21 \\
& Medium & 1.61 \\
\hline \multirow{2}{*}{ Kruskal-Wallis test } & Chi-squared & 12.392 \\
& Asymptotic sig. & $\mathbf{0 . 0 0 2}$ \\
\hline
\end{tabular}

Regarding evolution over time, a slight, statistically significant increase was noted globally in the average number of environmental practices performed by SMEs from 2014 to 2016 (Table 6). However, 
when we performed this analysis distinguishing by size, we did not find significant differences, except that in the group of small enterprises, the difference is marginally supported with a $p<0.10$ (Table 6).

Table 6. Value creation: evolution over time, globally, and by size.

\begin{tabular}{cccccc}
\hline & & All SMEs & Micro & Small & Medium \\
\hline \multirow{2}{*}{ Average values } & 2014 & 1.10 & 0.69 & 1.04 & 1.63 \\
& 2016 & 1.25 & 0.75 & 1.21 & 1.61 \\
\hline \multicolumn{2}{c}{ Kruskal-Wallis test } & & & & \\
Chi-squared & 4.322 & 1.517 & 3.774 & 0.063 \\
Asymptotic sig. & $\mathbf{0 . 0 3 8}$ & 0.218 & $\mathbf{0 . 0 5 2}$ & 0.802 \\
\hline
\end{tabular}

In spite of the slight improvement shown in the evolution over time analysis, the number of environmental practices performed by the SMEs is very low. We, therefore, consider it relevant to find which practices are the most widely adopted and if there are any differences in the degree of adoption depending on the size of the SMEs. Table 7 shows the percentage of adoption of each of the 9 practices and that most are not widely adopted among SMEs. The most widely adopted is recycling, reuse and valorization of the firm's sub-products and waste, which is adopted by $47.6 \%$ of the SMEs, followed by environmental audits at $28.9 \%$. Of the seven remaining practices, two are adopted by less than $15 \%$, two by about $7 \%$, and three not even by $5 \%$.

Table 7. Percentage of adoption of environmental practices: differences by SME size.

\begin{tabular}{|c|c|c|c|c|c|}
\hline $\begin{array}{l}\text { Environmental } \\
\text { Practices }\end{array}$ & All SMEs & Micro & Small & Medium & $\begin{array}{l}\text { Significant Difference } \\
\text { in Size }\end{array}$ \\
\hline Environmental audits & $28.9 \%$ & $13.73 \%$ & $26.39 \%$ & $43.57 \%$ & $\begin{array}{c}\text { Chi-squared }=21.887 \\
\text { Asymptotic sig. }=\mathbf{0 . 0 0 0}\end{array}$ \\
\hline Eco-design & $3 \%$ & $1.96 \%$ & $2.38 \%$ & $5.71 \%$ & $\begin{array}{c}\text { Chi-squared }=4.360 \\
\text { Asymptotic sig. }=0.113\end{array}$ \\
\hline Eco-labeling & $3.9 \%$ & $1.96 \%$ & $3.57 \%$ & $5.71 \%$ & $\begin{array}{c}\text { Chi-squared }=1.890 \\
\text { Asymptotic sig. }=0.389\end{array}$ \\
\hline Life cycle analysis & $6.9 \%$ & $1.96 \%$ & $5.75 \%$ & $12.86 \%$ & $\begin{array}{c}\text { Chi-squared }=10.677 \\
\text { Asymptotic sig. }=\mathbf{0 . 0 0 5}\end{array}$ \\
\hline Best available techniques & $12.4 \%$ & $1.96 \%$ & $11.51 \%$ & $19.29 \%$ & $\begin{array}{c}\text { Chi-squared }=11.600 \\
\text { Asymptotic sig. }=\mathbf{0 . 0 0 3}\end{array}$ \\
\hline $\begin{array}{l}\text { Recycling and reuse of } \\
\text { sub-products and waste }\end{array}$ & $47.6 \%$ & $29.41 \%$ & $47.82 \%$ & $53.57 \%$ & $\begin{array}{c}\text { Chi-squared }=8.762 \\
\text { Asymptotic sig. }=\mathbf{0 . 0 1 3}\end{array}$ \\
\hline $\begin{array}{l}\text { Recycling and/or waste } \\
\text { to generate energy }\end{array}$ & $14.1 \%$ & $15.69 \%$ & $14.09 \%$ & $13.57 \%$ & $\begin{array}{c}\text { Chi-squared }=0.138 \\
\text { Asymptotic sig. }=0.933\end{array}$ \\
\hline $\begin{array}{l}\text { Cogeneration and } \\
\text { trigeneration }\end{array}$ & $1.4 \%$ & $1.96 \%$ & $1.39 \%$ & $1.43 \%$ & $\begin{array}{c}\text { Chi-squared }=0.107 \\
\text { Asymptotic sig. }=0.948\end{array}$ \\
\hline $\begin{array}{l}\text { Inclusion of renewable } \\
\text { energy }\end{array}$ & $7.2 \%$ & $5.88 \%$ & $7.74 \%$ & $5.71 \%$ & $\begin{array}{c}\text { Chi-squared }=0.813 \\
\text { Asymptotic sig. }=0.666\end{array}$ \\
\hline
\end{tabular}

Table 7 also shows if there are any differences in the percentage of adoption of these environmental practices depending on size. The results vary and depend on the technique analyzed. For example, we found that in 4 of the 6 practices related to the generation of green products and processes (recycling and reuse of sub-products, environmental audits, analysis of best available techniques and life cycle analysis), there are significant differences by size in the percentage of adoption in SMEs. The table shows that in some cases, the differences are fairly large. In the other two product generation practices (eco-design and eco-labeling), even though there are differences in the percentages of adoption, 
these are not statistically significant. Regarding the three practices relating to power generation, none of them shows statistically significant differences in the percentage of adoption in terms of size.

\subsection{Green BMs: Value Capture}

The third component of BMs, value capture measured by $\mathrm{CO}_{2}$ productivity, has an average value of 62.87 (Table 2), and no significant differences were observed for this variable among firms of different sizes (Table 8 ).

Table 8. Value capture: differences by size.

\begin{tabular}{ccc}
\hline & Size & Value Capture \\
\hline \multirow{2}{*}{ Average values } & Micro & 48.52 \\
& Small & 54.67 \\
& Medium & 97.02 \\
\hline \multirow{2}{*}{ Kruskal-Wallis test } & Chi-squared & 0.870 \\
& Asymptotic sig. & 0.647 \\
\hline
\end{tabular}

In evolution over time of value capture, we noted a statistically significant increase in carbon productivity between 2014 and 2016. In evolution over time by size, we also found a statistically significant increase between micro and small enterprises. The increase in medium-sized enterprises is not statistically significant (Table 9).

Table 9. Value capture: evolution over time, globally, and by size.

\begin{tabular}{cccccc}
\hline & All SMEs & Micro & Small & Medium \\
\hline \multirow{2}{*}{ Average values } & 2014 & 52.90 & 38.95 & 50.53 & 72.52 \\
& 2016 & 62.87 & 48.52 & 54.67 & 97.02 \\
\hline \multicolumn{2}{c}{ Kruskal-Wallis test } & & & & \\
Chi-squared & 9.185 & 5.357 & 5.669 & 0.497 \\
Asymptotic sig. & $\mathbf{0 . 0 0 2}$ & $\mathbf{0 . 0 2 1}$ & $\mathbf{0 . 0 1 7}$ & 0.481 \\
\hline
\end{tabular}

\subsection{Green BMs: Relationships among Components}

We start by analyzing whether firms whose value proposition places greater importance on reducing environmental impact (whether legally required or voluntary) are also more committed to value creation and capture.

Table 10 shows that firms that place greater importance on legally required or voluntary reduction of their environmental impact also in general adopt more environmental initiatives, and the differences are significant (Table 7). The firms that place great importance on the legally required and voluntary value proposition include two environmental initiatives, while those that place little importance on it barely include one. If we analyze these differences according to business size, they are also significant in the groups of small and medium enterprises. 
Table 10. Differences between value proposition and creation: influence of size.

\begin{tabular}{cccccc}
\hline & & \multicolumn{3}{c}{ Value Creation } \\
\cline { 3 - 5 } & & All SMEs & Micro & Small & Medium \\
\hline \multirow{4}{*}{ Legal proposition } & Little importance & 0.856 & 1 & 0.80 & 1.09 \\
& Medium importance & 1.641 & 0.67 & 1.50 & 2.33 \\
& High importance & 1.97 & 1.75 & 1.93 & 2.28 \\
& Chi-squared & 44.157 & 2.646 & 36.451 & 8.638 \\
& Asymptotic sig. & $\mathbf{0 . 0 0 0}$ & 0.266 & $\mathbf{0 . 0 0 0}$ & $\mathbf{0 . 0 1 3}$ \\
\hline \multirow{5}{*}{ Voluntary proposition } & Little importance & 0.786 & 0.80 & 0.74 & 1.05 \\
& Medium importance & 1.699 & 1.25 & 1.55 & 2.22 \\
& High importance & 2.164 & 1.50 & 2.15 & 2.50 \\
& Chi-squared & 60.899 & 0.779 & 50.176 & 9.620 \\
& Asymptotic sig. & $\mathbf{0 . 0 0 0}$ & 0.677 & $\mathbf{0 . 0 0 0}$ & $\mathbf{0 . 0 0 8}$ \\
\hline
\end{tabular}

Regarding whether the importance of the environmental value proposition affects value capture, we did not obtain any statistically significant difference. Finally, we also studied whether the greater or lesser creation of environmental value measured by the number of initiatives adopted by firms had a significant effect on the capture of environmental value but found no significant differences.

\section{Conclusions}

Transformation toward a low-carbon economy requires participation by society as a whole, and SMEs, which constitute the bulk of the business fabric in all countries, have a special role to play. However, the few studies performed in the environment field have mainly focused on large corporations, and the analysis of SMEs has been limited to specific cases that are particularly environmentally proactive. However, what happens in most SMEs? How are such enterprises dealing with climate change? The BM literature tells us that innovation in BMs is especially accessible for SMEs and that when it includes environmental aspects, it can help in the process of transformation toward low-carbon economies. Are SMEs really participating extensively in this process?

The purpose of our study is to analyze how SMEs include product and process decarbonization in their BMs and how their size affects this inclusion. We used a database with 1161 observations on SMEs, 466 in 2014, and 695 in 2016.

The results show that, in general, SMEs are not widely incorporating decarbonization in their BMs and there are almost no significant differences by size. More specifically, the value proposition places medium importance on both legally required and voluntary reduction of the firm's environmental impact, whatever the size of the SME and the year analyzed. The ambivalent role of size discussed in the theory explains why there are no significant differences in this respect.

Moreover, the fact that the value propositions of SMEs regarding legally required and voluntary reduction of environmental impact are very similar and remain unchanged over time (also among SMEs of different sizes) seems to indicate that more rigorous regulations might have an influence on managers' environmental awareness. This is a possible avenue for future research.

Regarding the creation of environmental value, SMEs are adopting very few practices to help reduce $\mathrm{CO}_{2}$ emissions. In 2016, $43.3 \%$ did not adopt any practice and $37.7 \%$ only adopted one or two. In this respect, there are significant differences according to SME size and over time, although the average values are always very low. Thus, it seems that the difficulties stemming from the small size of SMEs, such as lack of knowledge, lack of human and financial resources, or general dependence on a small number of clients, outweigh the advantages. We consider that the definition of environmental practices adapted to SMEs and the training of managers might help enhance the value propositions of SMEs' green BMs.

Finally, and regarding value capture ( $\mathrm{CO}_{2}$ productivity), size is not very relevant, although there is a positive and significant evolution over time that is maintained in micro and small enterprises. 
We believe the economic recovery of the Spanish economy over recent years, which has led to improved sales, might be the reason for this improved ratio.

It is also of interest that, in this component, there is no significant difference between the firms that adopt most environmental initiatives and those that place greater importance on legal compliance or voluntary reduction of their environmental impact. This shows that not only do they adopt few environmental practices, but that these are not effective for reducing carbon. an explanation for this result might lie in the fact that the practices that are most widely adopted by SMEs, that is, recycling and environmental audits, are not very effective for reducing carbon. It is, therefore, important for SMEs to adopt more effective practices for carbon reduction (or specific adaptations of such practices for SMEs), such as product life cycle, eco-design, or alternative power generation.

This diagnosis of green BMs shows that SMEs need the help of the administration if they are to play a key role in the process of transformation of societies toward a low-carbon economy. Legislative actions that impose tougher environmental protection measures might help lead to value propositions that place greater importance on reducing environmental impact. Training actions on available environmental techniques and the promotion of research on the adaptation of such techniques to SMEs, as well as the adoption of specific practices for SMEs, might help enhance environmental value creation and capture in their BMs.

This research is not free from limitations, which point to future research directions. First, although it provides interesting findings on how SMEs of different sizes include decarbonization in their business models, the facts that the sample is small and only includes Galician firms mean that the results cannot be generalized to other regions or companies. It would, therefore, be of interest to expand the sample to include firms from other regions or countries and to analyze similarities and differences. Additionally, although the exploratory nature of the study is a strength from the empirical point of view, since most field studies are case studies, it would be of interest to analyze the causal, mediating, and/or moderating relations in the constructs studied using multi-variate analysis. Finally, as survey data for additional years become available, the time frame of the analysis can be expanded.

Author Contributions: M.A.Q. designed the research and drew up the theoretical framework. A.I.M.-S. and A.S. analyzed the data and discussed the empirical results. All the authors read and drew up the final manuscript.

Acknowledgments: This work has received financial support from the Spanish Government through grant ECO2016-76625-R.

Conflicts of Interest: The authors declare no conflicts of interest.

\section{References}

1. Renukappa, S.; Akintoye, A.; Egbu, C.; Goulding, J. Carbon emission reduction strategies in the UK industrial sectors: An empirical study. Int. J. Clim. Chang. Strateg. Manag. 2013, 5, 304-323. [CrossRef]

2. Lee, S. Corporate carbon strategies in responding to climate change. Bus. Strategy Environ. 2012, 21, 33-48. [CrossRef]

3. Hartmann, J.; West, A.J.; Renforth, P.; Köhler, P.; De La Rocha, C.L.; Wolf-Gladrow, D.A.; Dürr, H.H.; Scheffran, J. Enhanced chemical weathering as a geoengineering strategy to reduce atmospheric carbon dioxide, supply nutrients, and mitigate ocean acidification. Rev. Geophys. 2013, 51, 113-149. [CrossRef]

4. Monitor Deloitte. A Sustainable Energy Model for Spain in 2050. Policy Recommendations for the Energy Transition; Monitor Deloitte: Madrid, Spain, 2016.

5. Rogelj, J.; Luderer, G.; Pietzcker, R.C.; Kriegler, E.; Schaeffer, M.; Krey, V.; Riahi, K. Energy system transformations for limiting end-of-century warming to below 1.5 C. Nat. Clim. Chang. 2015, 5, 519-527. [CrossRef]

6. Damert, M.; Paul, A.; Baumgartner, R.J. Exploring the determinants and long-term performance outcomes of corporate carbon strategies. J. Clean. Prod. 2017, 160, 123-138. [CrossRef]

7. Long, T.B.; Looijen, A.; Blok, V. Critical success factors for the transition to business models for sustainability in the food and beverage industry in the Netherlands. J. Clean. Prod. 2018, 175, 82-95. [CrossRef] 
8. Schaltegger, S.; Lüdeke-Freund, F.; Hansen, E.G. Business cases for sustainability: The role of business model innovation for corporate sustainability. Int. J. Innov. Sustain. Dev. 2012, 6, 95-119. [CrossRef]

9. Schaltegger, S.; Hansen, E.G.; Lüdeke-Freund, F. Business Models for Sustainability: Origins, Present Research, and Future Avenues. Organ. Environ. 2016, 29, 3-10. [CrossRef]

10. Weinhofer, G.; Busch, T. Corporate strategies for managing climate risks. Bus. Strategy Environ. 2013, 22, 121-144. [CrossRef]

11. Weinhofer, G.; Hoffmann, V.H. Mitigating climate change-how do corporate strategies differ? Bus. Strategy Environ. 2010, 19, 77-89. [CrossRef]

12. Delmas, M.; Toffel, M.W. Stakeholders and environmental management practices: an institutional framework. Bus. Strategy Environ. 2004, 13, 209-222. [CrossRef]

13. Jennings, P.D.; Zandbergen, P.A. Ecologically sustainable organizations: an institutional approach. Acad. Manag. Rev. 1995, 20, 1015-1052. [CrossRef]

14. Buysse, K.; Verbeke, A. Proactive environmental strategies: a stakeholder management perspective. Strateg. Manag. J. 2003, 24, 453-470. [CrossRef]

15. Zhang, H.; Yang, F. On the drivers and performance outcomes of green practices adoption. Ind. Manag. Data Syst. 2016, 116, 2011-2034. [CrossRef]

16. Yu, W.; Ramanathan, R. an empirical examination of stakeholder pressures, green operations practices and environmental performance. Int. J. Prod. Res. 2015, 53, 6390-6407. [CrossRef]

17. Judge, W.Q.; Douglas, T.J. Performance implications of incorporating natural environmental issues into the strategic planning process: an empirical assessment. J. Manag. Stud. 1998, 35, 241-262. [CrossRef]

18. Aragón-Correa, J.A.; Sharma, S. a contingent resource-based view of proactive corporate environmental strategy. Acad. Manag. Rev. 2003, 28, 71-88. [CrossRef]

19. Sharma, S. Managerial interpretations and organizational context as predictors of corporate choice of environmental strategy. Acad. Manag. J. 2000, 43, 681-697.

20. Cook, J.; Nuccitelli, D.; Green, S.A.; Richardson, M.; Winkler, B.; Painting, R.; Way, R.; Jacobs, P.; Skuce, A. Quantifying the consensus on anthropogenic global warming in the scientific literature. Environ. Res. Lett. 2013, 8, 024024. [CrossRef]

21. Mangelsdorf, M.E. How Fast Can Innovations Get Big? MIT Sloan Manag. Rev. 2010, 52, 96.

22. Richardson, J. The business model: an integrative framework for strategy execution. Strateg. Chang. 2008, 17, 133-144. [CrossRef]

23. Bocken, N.; Short, S.W.; Rana, P.; Evans, S. a literature and practice review to develop sustainable business model archetypes. J. Clean. Prod. 2014, 65, 42-56. [CrossRef]

24. Casadesus Masanell, R.; Richart, J.E. From Strategy to Business Models and onto Tactics. Long Range Plan. 2010, 43, 195. [CrossRef]

25. Wainstein, M.E.; Bumpus, A.G. Business models as drivers of the low carbon power system transition: a multi-level perspective. J. Clean. Prod. 2016, 126, 572-585. [CrossRef]

26. Hannon, M.J.; Foxon, T.J.; Gale, W.F. The co-evolutionary relationship between Energy Service Companies and the UK energy system: Implications for a low-carbon transition. Energy Policy 2013, 61, 1031-1045. [CrossRef]

27. Karneyeva, Y.; Wüstenhagen, R. Solar feed-in tariffs in a post-grid parity world: The role of risk, investor diversity and business models. Energy Policy 2017, 106, 445-456. [CrossRef]

28. Hiteva, R.; Sovacool, B. Harnessing social innovation for energy justice: a business model perspective. Energy Policy 2017, 107, 631-639. [CrossRef]

29. Rajala, R.; Westerlund, M.; Lampikoski, T. Environmental sustainability in industrial manufacturing: Re-examining the greening of Interface's business model. J. Clean. Prod. 2016, 115, 52-61. [CrossRef]

30. Andersen, M.M. Frugal Innovation and Green Business Models. Proc. ISPIM Conf. 2015, 1, 1-19.

31. Ritala, P.; Huotari, P.; Bocken, N.; Albareda, L.; Puumalainen, K. Sustainable business model adoption among S\&P 500 firms: a longitudinal content analysis study. J. Clean. Prod. 2018, 170, 216-226.

32. Boons, F.; Lüdeke-Freund, F. Business models for sustainable innovation: State-of-the-art and steps towards a research agenda. J. Clean. Prod. 2013, 45, 9-19. [CrossRef]

33. Viesi, D.; Pozzar, F.; Federici, A.; Crema, L.; Mahbub, M.S. Energy efficiency and sustainability assessment of about 500 small and medium-sized enterprises in Central Europe region. Energy Policy 2017, 105, 363-374. [CrossRef] 
34. Hillary, R. Small and Medium-Sized Enterprises and the Environment: Business Imperatives; Routledge: Abingdon-on-Thames, UK, 2017.

35. Blundel, R.; Monaghan, A.; Thomas, C. SMEs and environmental responsibility: a policy perspective. Bus. Ethics Eur. Rev. 2013, 22, 246-262. [CrossRef]

36. Revell, A.; Blackburn, R. The business case for sustainability? an examination of small firms in the UK's construction and restaurant sectors. Bus. Strategy Environ. 2007, 16, 404-420. [CrossRef]

37. Johnson, M.P. Sustainability management and small and medium-sized enterprises: Managers' awareness and implementation of innovative tools. Corp. Soc. Responsib. Environ. Manag. 2015, 22, 271-285. [CrossRef]

38. Schaltegger, S.; Lüdeke-Freund, F.; Hansen, E.G. Business Models for Sustainability: a Co-Evolutionary Analysis of Sustainable Entrepreneurship, Innovation, and Transformation. Organ. Environ. 2016, 29, 264-289. [CrossRef]

39. Abuzeinab, A.; Arif, M.; Qadri, M.A.; Kulonda, D. Green business models in the construction sector: an analysis of outcomes and benefits. Constr. Innov. 2018, 18, 20-42. [CrossRef]

40. Bidmon, C.M.; Knab, S.F. The three roles of business models in societal transitions: New linkages between business model and transition research. J. Clean. Prod. 2017, 178, 903-916. [CrossRef]

41. Parrish, B.D.; Foxon, T.J. Sustainability Entrepreneurship and Equitable Transitions to a Low-Carbon Economy. Greener Manag. Int. 2009, 55, 47-62. [CrossRef]

42. Rauter, R.; Jonker, J.; Baumgartner, R.J. Going one's own way: Drivers in developing business models for sustainability. J. Clean. Prod. 2017, 140, 144-154. [CrossRef]

43. Williams, S.; Schaefer, A. Small and medium-sized enterprises and sustainability: Managers' values and engagement with environmental and climate change issues. Bus. Strategy Environ. 2013, 22, 173-186. [CrossRef]

44. Rizos, V.; Behrens, A.; Van Der Gaast, W.; Hofman, E.; Ioannou, A.; Kafyeke, T.; Flamos, A.; Rinaldi, R.; Papadelis, S.; Hirschnitz-Garbers, M. Implementation of circular economy business models by small and medium-sized enterprises (SMEs): Barriers and enablers. Sustainability 2016, 8, 1212. [CrossRef]

45. Wirtz, B. Business Models: Origin, Development and Future Research Perspectives. Long Range Plan. 2016, 49, 36. [CrossRef]

46. Kennedy, C.; Stewart, I.D.; Facchini, A.; Mele, R. The role of utilities in developing low carbon, electric megacities. Energy Policy 2017, 106, 122-128. [CrossRef]

47. Madina, C.; Zamora, I.; Zabala, E. Methodology for assessing electric vehicle charging infrastructure business models. Energy Policy 2016, 89, 284-293. [CrossRef]

48. Foss, N.J.; Saebi, T. Fifteen Years of Research on Business Model Innovation. J. Manag. 2017, 43, $200-227$. [CrossRef]

49. Yang, M.; Evans, S.; Vladimirova, D.; Rana, P. Value uncaptured perspective for sustainable business model innovation. J. Clean. Prod. 2017, 140, 1794-1804. [CrossRef]

50. Massa, L.; Tucci, C.; Afuah, A. a critical assessment of business model research. Acad. Manag. Ann. 2017, 11, 73-104. [CrossRef]

51. George, G.; Bock, A.J. The Business Model in Practice and its Implications for Entrepreneurship Research. Entrep. Theory Pract. 2011, 35, 83-111. [CrossRef]

52. Zott, C.; Amit, R.; Massa, L. The Business Model: Recent Developments and Future Research. J. Manag. 2011, 37, 1019-1042.

53. Lambert, S.C.; Davidson, R.A. Applications of the business model in studies of enterprise success, innovation and classification: an analysis of empirical research from 1996 to 2010. Eur. Manag. J. 2013, 31, 668-681. [CrossRef]

54. Spieth, P.; Schneckenberg, D.; Matzler, K. Exploring the linkage between business model (\&) innovation and the strategy of the firm. RED Manag. 2016, 46, 403-413.

55. Teece, D.J. Business models, business strategy and innovation. Long Range Plan. 2010, 43, 172-194. [CrossRef]

56. Cortimiglia, M.N.; Ghezzi, A.; Frank, A.G. Business model innovation and strategy making nexus: Evidence from a cross-industry mixed-methods study. RED Manag. 2016, 3, 414-432.

57. Schneider, S.; Spieth, P. Business Model Innovation: Towards an Integrated Future Research Agenda. Int. J. Innov. Manag. 2013, 17, 1340001. [CrossRef]

58. Nidumolu, R.; Prahalad, C.K.; Rangaswami, M.R. Why sustainability is now the key driver of innovation. Harv. Bus. Rev. 2009, 87, 56-64. 
59. Hart, S.L. a natural-resource-based view of the firm. Acad. Manag. Rev. 1995, 20, 986-1014. [CrossRef]

60. Boiral, O. Global Warming: Should Companies Adopt a Proactive Strategy? Long Range Plan. 2006, 39, 315-330. [CrossRef]

61. Hoffman, A.J. Climate Change Strategy: The Business Logic behind Voluntary Greenhouse Gas Reductions. Calif. Manag. Rev. 2005, 47, 21-46. [CrossRef]

62. Hoffman, A.J. Carbon Strategies: How Leading Companies Are Reducing Their Climate Change Footprint; University of Michigan Press: Ann Arbor, MI, USA, 2007.

63. Kolk, A.; Pinkse, J. Business Responses to Climate Change: Identifying Emergent Strategies. Calif. Manag. Rev. 2005, 47, 6-20. [CrossRef]

64. Wahyuni, D.; Ratnatunga, J. Carbon strategies and management practices in an uncertain carbonomic environment-Lessons learned from the coal-face. J. Clean. Prod. 2015, 96, 397-406. [CrossRef]

65. Cadez, S.; Czerny, A. Climate change mitigation strategies in carbon-intensive firms. J. Clean. Prod. 2016, 112, 4132-4143. [CrossRef]

66. Backman, C.A.; Verbeke, A.; Schulz, R.A. The drivers of corporate climate change strategies and public policy: a new resource-based view perspective. Bus. Soc. 2017, 56, 545-575. [CrossRef]

67. Okereke, C.; Russel, D. Regulatory Pressure and Competitive Dynamics: Carbon Management Strategies of UK Energy-Intensive Companies. Calif. Manag. Rev. 2010, 52, 100-124. [CrossRef]

68. Busch, T.; Lewandowski, S. Corporate Carbon and Financial Performance: a Meta-analysis. J. Ind. Ecol. 2017. [CrossRef]

69. Moniz, E.J. Why size matters. MIT Sloan Manag. Rev. 2010, 52, 1.

70. Clinton, L.; Whisnant, R. Model behavior. 20 Business Model Innovations for Sustainability. In Managing Sustainable Business; Springer: Dordrecht, the Netherlands, 2019.

71. Halme, M.; Korpela, M. Responsible Innovation toward Sustainable Development in Small and Medium-Sized Enterprises: a Resource Perspective. Bus. Strategy Environ. 2014, 23, 547-566. [CrossRef]

72. Barbier, E.B. The concept of sustainable economic development. Environ. Conserv. 1987, 14, $101-110$. [CrossRef]

73. Abuzeinab, A.; Arif, M.; Qadri, M.A. Barriers to MNEs green business models in the UK construction sector: an ISM analysis. J. Clean. Prod. 2017, 160, 27-37. [CrossRef]

74. Morioka, S.N.; Bolis, I.; Evans, S.; Carvalho, M.M. Transforming sustainability challenges into competitive advantage: Multiple case studies kaleidoscope converging into sustainable business models. J. Clean. Prod. 2017, 167, 723-738. [CrossRef]

75. Lefebvre, É.; Lefebvre, L.A.; Talbot, S. Determinants and impacts of environmental performance in SMEs. RED Manag. 2003, 33, 263-283.

76. Urgal, B.; Quintás, M.Á.; Tomé, R.A. Conocimiento tecnológico, capacidad de innovación y desempeño innovador: El rol moderador del ambiente interno de la empresa. Cuadernos Economía Dirección Empresa 2011, 14, 53-66. [CrossRef]

77. Brammer, S.; Hoejmose, S.; Marchant, K. Environmental management in SMEs in the UK: Practices, pressures and perceived benefits. Bus. Strategy Environ. 2012, 21, 423-434. [CrossRef]

78. Tilley, F. The gap between the environmental attitudes and the environmental behaviour of small firms. Bus. Strategy Environ. 1999, 8, 238. [CrossRef]

79. Morioka, S.N.; Evans, S.; de Carvalho, M.M. Sustainable business model innovation: Exploring evidences in sustainability reporting. Procedia CIRP 2016, 40, 659-667. [CrossRef]

80. Levy, D.L.; Rothenberg, S. Heterogeneity and change in environmental strategy: Technological and political responses to climate change in the global automobile industry. In Organization, Policy and the Natural Environment: Institucional and Strategic Perspectives; Hoffman, A.J., Ventresca, M.J., Eds.; Stanford University Press: Stanford, CA, USA, 2002; pp. 173-193.

81. Ormazabal, M.; Puga-Leal, R. an exploratory study of UK companies' taxonomy based on environmental drivers. J. Clean. Prod. 2016, 133, 479-486. [CrossRef]

82. Wilson, C.D.; Williams, I.D.; Kemp, S. an evaluation of the impact and effectiveness of environmental legislation in small and medium-sized enterprises: Experiences from the UK. Bus. Strategy Environ. 2012, 21, 141-156. [CrossRef]

83. Simpson, M.; Taylor, N.; Barker, K. Environmental responsibility in SMEs: Does it deliver competitive advantage? Bus. Strategy Environ. 2004, 13, 156-171. [CrossRef] 
84. Miller, N.J.; Winter, M.; Fitzgerald, M.A.; Paul, J. Family microenterprises: Strategies for coping with overlapping family and business demands. J. Dev. Entrep. 2000, 5, 87.

85. Mir, D.F.; Feitelson, E. Factors affecting environmental behavior in micro-enterprises: Laundry and motor vehicle repair firms in Jerusalem. Int. Small Bus. J. 2007, 25, 383-415. [CrossRef]

86. Claver, E.; Lopez, M.D.; Molina, J.F.; Tarí, J.J. Environmental management and firm performance: a case study. J. Environ. Manag. 2007, 84, 606-619. [CrossRef] [PubMed]

87. Bradford, J.; Fraser, E.D. Local authorities, climate change and small and medium enterprises: Identifying effective policy instruments to reduce energy use and carbon emissions. Corp. Soc. Responsib. Environ. Manag. 2008, 15, 156-172. [CrossRef]

88. McKinnon, A.C. Product-level carbon auditing of supply chains: Environmental imperative or wasteful distraction? Int. J. Phys. Distrib. Logist. Manag. 2010, 40, 42-60. [CrossRef]

89. Kulatunga, A.K.; Karunatilake, N.; Weerasinghe, N.; Ihalawatta, R.K. Sustainable Manufacturing Based Decision Support Model for Product Design and Development Process. Procedia CIRP 2015, 26, 87-92. [CrossRef]

90. Chang, D.; Lee, C.; Chen, C. Review of life cycle assessment towards sustainable product development. J. Clean. Prod. 2014, 83, 48-60. [CrossRef]

91. Navarro, A.; Puig, R.; Fullana-i-Palmer, P. Product vs corporate carbon footprint: Some methodological issues. a case study and review on the wine sector. Sci. Total Environ. 2017, 581, 722-733. [CrossRef] [PubMed]

92. Galarraga Gallastegui, I. The use of eco-labels: a review of the literature. Environ. Policy Gov. 2002, 12, 316-331. [CrossRef]

93. Tang, E.; Fryxell, G.E.; Chow, C.S. Visual and verbal communication in the design of eco-label for green consumer products. J. Int. Consum. Market. 2004, 16, 85-105. [CrossRef]

94. Hartling, X. Design a Successful Program for Voluntary Carbon Footprint Reduction. Int. Rev. Adv. Bus. Manag. Law 2018, 1.

95. Madin, E.M.P.; Macreadie, P.I. Incorporating carbon footprints into seafood sustainability certification and eco-labels. Mar. Policy 2015, 57, 178-181. [CrossRef]

96. Gössling, S.; Buckley, R. Carbon labels in tourism: Persuasive communication? J. Clean. Prod. 2016, 111, 358-369. [CrossRef]

97. Burnett, J. City buildings-Eco-labels and shades of green! Landsc. Urban Plan. 2007, 83, 29-38. [CrossRef]

98. Ibáñez-Forés, V.; Bovea, M.D.; Azapagic, A. Assessing the sustainability of Best Available Techniques (BAT): Methodology and application in the ceramic tiles industry. J. Clean. Prod. 2013, 51, 162-176. [CrossRef]

99. Mancarella, P.; Chicco, G. Assessment of the greenhouse gas emissions from cogeneration and trigeneration systems. Part II: Analysis techniques and application cases. Energy 2008, 33, 418-430. [CrossRef]

100. Glavič, P.; Lukman, R. Review of sustainability terms and their definitions. J. Clean. Prod. 2007, 15, 1875-1885. [CrossRef]

101. Tam, V.W.Y.; Tam, C.M. Evaluations of existing waste recycling methods: a Hong Kong study. Build. Environ. 2006, 41, 1649-1660. [CrossRef]

102. Kang, H.; Schoenung, J.M. Electronic waste recycling: a review of U.S. infrastructure and technology options. Resour. Conserv. Recycl. 2005, 45, 368-400. [CrossRef]

103. Burke, S.; Gaughran, W.F. Intelligent environmental management for SMEs in manufacturing. Robot. Comput. Integr. Manuf. 2006, 22, 566-575. [CrossRef]

104. Brunner, P.H.; Rechberger, H. Waste to energy-Key element for sustainable waste management. Waste Manag. 2015, 37, 3-12. [CrossRef] [PubMed]

105. Nunes, L.J.; Godina, R.; Matias, J.C.; Catalão, J.P. Economic and environmental benefits of using textile waste for the production of thermal energy. J. Clean. Prod. 2018, 171, 1353-1360. [CrossRef]

106. Martens, A. The energetic feasibility of CHP compared to the separate production of heat and power. Appl. Therm. Eng. 1998, 18, 935-946. [CrossRef]

107. Chicco, G.; Mancarella, P. Assessment of the greenhouse gas emissions from cogeneration and trigeneration systems. Part I: Models and indicators. Energy 2008, 33, 410-417. [CrossRef]

108. Meunier, F. Co- and tri-generation contribution to climate change control. Appl. Therm. Eng. 2002, 22, 703-718. [CrossRef] 
109. Panwar, N.L.; Kaushik, S.C.; Kothari, S. Role of renewable energy sources in environmental protection: a review. Renew. Sustain. Energy Rev. 2011, 15, 1513-1524. [CrossRef]

110. Martinez-Senra, A.I.; Quintás, M.A.; Sartal, A.; Vázquez, X.H. How can firms' basic research turn into product innovation? The role of absorptive capacity and industry appropriability. IEEE Trans. Eng. Manag. 2015, 62, 205-216. [CrossRef]

111. Bowen, F.E. Does size matter? Organizational slack and visibility as alternative explanations for environmental responsiveness. Bus. Soc. 2002, 41, 118-124. [CrossRef]

112. Hammann, E.; Habisch, A.; Pechlaner, H. Values that create value: Socially responsible business practices in SMEs-empirical evidence from German companies. Bus. Ethics Eur. Rev. 2009, 18, 37-51. [CrossRef]

113. Ghezzi, A.; Cortimiglia, M.N.; Frank, A.G. Strategy and business model design in dynamic telecommunications industries: a study on Italian mobile network operators. Technol. Forecast. Soc. Chang. 2015, 90, 346-354. [CrossRef]

114. Sorescu, A.; Frambach, R.T.; Singh, J.; Rangaswamy, A.; Bridges, C. Innovations in Retail Business Models. J. Retail. 2011, 87, S3-S16. [CrossRef]

115. Amit, R.; Zott, C. Value creation in e-business. Strateg. Manag. J. 2001, 22, 493-520. [CrossRef]

116. Osterwalder, A.; Pigneur, Y.; Tucci, C.L. Clarifying business models: Origins, present, and future of the concept. Commun. Assoc. Inf. Syst. 2005, 16, 1-25.

117. CZFV. Galician Innovation Survey; Zona Franca: Galician, Spain, 2017; Available online: http:/ / www.zfv.es / innobench/ (accessed on 1 June 2018).

118. Phillips, L.W. Assessing measurement error in key informant reports: a methodological note on organizational analysis in marketing. J. Mark. Res. 1981, 18, 395-415. [CrossRef]

119. Armstrong, J.S.; Overton, T.S. Estimating nonresponse bias in mail surveys. J. Mark. Res. 1977, 14, $396-402$. [CrossRef]

120. Sartal, A.; Llach, J.; Vázquez, X.H.; de Castro, R. How much does Lean Manufacturing need environmental and information technologies. J. Manuf. Syst. 2017, 45, 260-272. [CrossRef]

121. Xu, X.Y.; Ang, B.W. Index decomposition analysis applied to $\mathrm{CO}_{2}$ emission studies. Ecol. Econ. 2013, 93, 313-329. [CrossRef]

122. Agreement, P. United Nations Framework Convention on Climate Change; United Nations: Paris, France, 2015; Available online: https:/ /unfccc.int/resource/docs/2015/cop21/eng/109r01.pdf (accessed on 1 February 2018).

123. European Union. EU Resource Efficiency Scoreboard 2015; European Union: Brussels, Belgium, 2016.

124. Rodríguez, M.; Pena-Boquete, Y. Carbon intensity changes in the Asian Dragons. Lessons for climate policy design. Energy Econ. 2017, 66, 17-26. [CrossRef]

125. Intergovernmental Panel on Climate Change. Climate Change 2014: Mitigation of Climate Change; Cambridge University Press: Cambridge, UK, 2015.

126. Shao, C.; Guan, Y.; Wan, Z.; Guo, C.; Chu, C.; Ju, M. Performance and decomposition analyses of carbon emissions from industrial energy consumption in Tianjin, China. J. Clean. Prod. 2014, 64, 590-601. [CrossRef]

127. Sartal, A.; Senra, A.I.M.; Cruz-Machado, V. Are all Lean Principles Equally Eco-Friendly? a Panel Data Study. J. Clean. Prod. 2017. [CrossRef]

(C) 2018 by the authors. Licensee MDPI, Basel, Switzerland. This article is an open access article distributed under the terms and conditions of the Creative Commons Attribution (CC BY) license (http:/ / creativecommons.org/licenses/by/4.0/). 